\title{
False positive anti-hepatitis A virus IgM result in a patient with autoimmune hepatitis
}

\author{
JAMES R. GRAY, MD, URS P. STEINBRECHER, MD
}

\begin{abstract}
This report describes a patient with autoimmune hepatitis in whom a positive test result for hepatitis A virus (HAV) $\operatorname{IgM}$ antibody led to diagnostic confusion until it was shown to be false positive by immunoprecipitation of $\operatorname{IgG}$ from serum. The mechanism for the false positive result may have been related to marked hypergammaglobulinemia, as serum obtained after normalization of immunoglobulin levels tested negative. However, several other mechanisms were also considered. This case illustrates that the possibility of false positive results with the anti-HAV IgM assay should be kept in mind when the clinical features of the illness are not suggestive of acute hepatitis A. Can J Gastroenterol 1989; $3(3): 115-118$
\end{abstract}

Key Words: Autoimmune hepatitis, Chronic active hepatitis, Hepatitis A, IgM serologic tests

\section{Résultat faux positif d'anti-HAV dans les IgM sériques d'un patient atteint d'hépatite autoimmune}

RESUME: Ce rapport décrit le cas d'un patient atteint d'hépatite autoimmune pour qui le test a donné un résultat positif d'anti-HAV dans les IgM. Ceci a entraîné une confusion dans le diagnostic jusqu'à ce que l'on découvre que le résultat en question était dû à l'immunoprécipitation des IgG sériques. Le mécanisme expliquant ce résultat faux positif est peut-être relié à une hypergammaglobulinémie marquée, le sérum obtenu après la normalization des niveaux d'immunoglobulines ayant donné un résultat négatif; plusieurs autres mécanismes ont toutefois été étudiés. Ce cas démontre que la possibilité des résultats faux positifs portant sur les anti-HAV doit être contemplée quand les signes cliniques de la maladie n'indiquent pas une hépatite $A$ aiguë.

Division of Gastroenterology, Department of Medicine, University of British Columbia, Vancouver, British Columbia

Correspondence and reprints: Dr Urs P. Steinbrecher. Department of Medicine, Division of Gastroenterology, University of British Columbia, 2211 Wesbrook Mall, Vancouver, British Columbia V6T 1W5. Telephone (604) 228-7727

Received for publication August 23, 1988. Accepted December 19, 1988 $\prod$ HE MOST WIDELY USED SERODIAGvirus (HAV) infection involve immunoassays for HAV specific $\operatorname{lgM}(1,2)$. Commercially available test kits are sensitive solid phase $\lg M$ capture assays with radioimmunometric or enzyme immunometric detection and quantitation (3). There have been very few reported false positive results and the specificity of a positive anti-HAV $\operatorname{IgM}$ result is, therefore, assumed to be high (4). This report describes a patient with symptoms suggesting hepatitis, in whom an unexpected positive anti-HAV IgM result led to diagnostic confusion until it was demonstrated to be a false positive result due to interfering $\mathrm{IgG}$ in the plasma. The following case is the first published report of a false positive anti-HAV IgM enzyme immunoassay result and should alert clinicians to this possibility when unexpected positive anti-HAV IgM results are encountered.

\section{CASE PRESENTATION}

A 70-year-old caucasian woman presented with a six week history of fatigue, malaise and anorexia. Other than some moderate exertional dyspnea of six months duration, the patient had pre- 
viously been in good health. There was no prior history of jaundice or liver disease. The patient had never received blood products and reported no contact with jaundiced individuals, alcohol or exposure to potentially hepatotoxic drugs. Initial physical examination showed mild icterus, multiple spider angiomas and dry rales at both lung bases. The liver was normal in size with a somewhat blunt edge but no nodularity. There was no splenomegaly or ascites.

Presenting laboratory observations were: bilirubin $44 \mu \mathrm{mol} / \mathrm{L}$; aspartate aminotransferase $500 \mathrm{iu} / \mathrm{L}$; alkaline phosphatase $160 \mathrm{iu} / \mathrm{L}$; albumin $23 \mathrm{~g} / \mathrm{L}$; globulin $63 \mathrm{~g} / \mathrm{L}$; prothrombin time $14 \mathrm{~s}$; antinuclear antibody positive to $1: 80 \mathrm{di}$ lution; positive antismooth muscle antibody; and negative hepatitis $B$ surface antigen $(\mathrm{HBs} A g)$ and anti- $\mathrm{HBc}$. A chest $\mathrm{x}$-ray revealed a diffuse fine reticulonodular infiltrate. Pulmonary function tests demonstrated a decreased total lung capacity, normal flow rates and normal diffusing capacity. A liver biopsy showed expansion of the portal tracts with a heavy infiltrate of lymphocytes and plasma cells, piecemeal necrosis and focal lobular inflammation and disarray (Figure 1). On the basis of these clinical and pathologic findings a diagnosis of auto-

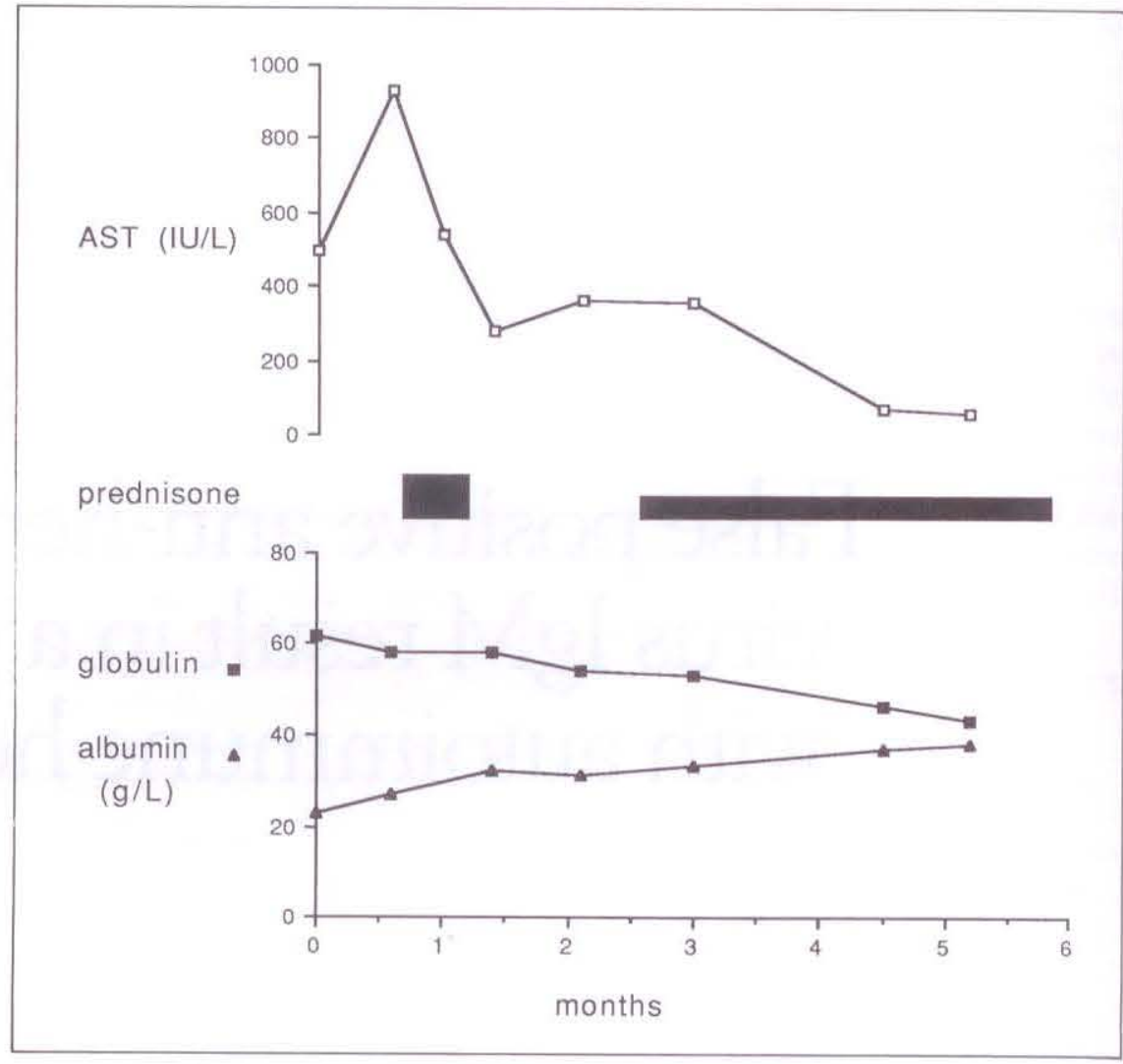

Figure 2) Evolution of biochemical test results with treatment

immune chronic hepatitis with associated interstitial lung disease was made.

Prednisone was started at an initial dose of $30 \mathrm{mg} /$ day and there was a



Figure 1) Liver biopsy showing expansion of the portal tracts with a heavy infiltrate of lymphocytes and plasma cells, piecemeal necrosis and focal lobular inflammation and disarray. Hematoxylin and $\operatorname{cosin}(\times 225)$ prompt symptomatic and biochemical improvement. Two weeks after the start of corticosteroid therapy, a positive antiHAV IgM result was received (HAVABM, Abbott Laboratories, North Chicago, IL) and was subsequently confirmed on two repeat determinations over a period of four months. Corticosteroids were discontinued and over the next few weeks the patient noted recurrence of anorexia and fatigue; transaminases also increased somewhat (Figure 2).

The virology department of the British Columbia Provincial Laboratory of Public Health was contacted and was asked to examine the patient's sera for factors that might have caused a false positive result. Three separate serum samples drawn over a period of four months gave spectrophotometer absorbance values about twice that of the cutoff value (serum 0.167 , cutoff 0.074 ). Although unquestionably abnormal, the values were considerably lower than those usually seen in patients with acute hepatitis A. When the assay was done without HAV antigen in the reaction sequence, the results were negative. All serum samples were 
retested after addition of sheep antihuman IgG (RF Absorbent, Behring, Marburg, West Germany) and the results were then found to be negative.

Immunosuppressive therapy was resumed with prednisone $10 \mathrm{mg} /$ day and azathioprine $50 \mathrm{mg} /$ day and all symptoms and biochemical abnormalities resolved over the next few months.

\section{DISCUSSION}

Although anti-HAV $\operatorname{lgM}$ is evidently a sensitive and fairly specific diagnostic test, there is one previous report of false positive anti-HAV $\operatorname{lgM}$ results using a radioimmunoassay method (5). In that report, six patients with remote acute hepatitis $A$ were found to have persistently positive tests for anti-HAV $\operatorname{IgM}$, thought to be due to HAV specific $\operatorname{Ig} A$ with rheumatoid factor activity. In the present case, removal of $\mathrm{lg} G$ from patient serum with monospecific precipitating antibody abolished the reactivity, indicating that the positive result was not $\lg M$ specific and hence was false positive.

The best commercially available assays for anti-HAV IgM are IgM capture solid phase radioimmunoassay or enzyme immunoassay. The design of these assays involves matrix beads coated with antibody to human $\lg \mathrm{M}$. Test serum is added and any $\lg \mathrm{M}$ contained in it is bound to the beads. Unbound serum components are removed by washing and $\mathrm{HAV}$ antigen is then added. If $\lg \mathrm{M}$ anti-HAV is present, the added HAV antigen will be bound to the bead by this antibody. Antibody to HAV which has been radioiodinated or coupled to horseradish peroxidase is then added and its binding will be in proportion to the amount of HAV antigen bound. The beads are then assayed for radioactivity (radioimmunoassay), or colour development after addition of o-phenylenedia-

ACKNOWLEDGEMENTS: The authors thank Dr H. Kubinski for referring the patient and DrP.J. Middleton for performing the serodiagnostic tests for $\mathrm{HAV}$.

\section{REFERENCES}

1. Lemon SM. Type A viral hepatitis. N Engl J Med 1985;313:1059-67.

2. Dienstag JL, Wands JR, Koff RS. Acute hepatitis. In: Braunwald E, Isselbacher mine and hydrogen peroxide (enzyme immunoassay) to quantify antibody binding.

One well known cause of false positive results with serodiagnostic tests for pathogen specific IgM is rheumatoid factor activity in patient serum $(6,7)$. Rheumatoid factors are $\lg \mathrm{M}$ antibodies directed against homologous IgG. They are of obvious importance in rheumatoid arthritis and can also be associated with other systemic inflammatory or infectious conditions as well as occasionally being present in healthy normal subjects. It has been found that even very low concentrations of rheumatoid factor can interfere with immunoassays and in such cases the relatively insensitive latex agglutination tests for theumatoid factor that are in routine use for evaluation of rheumatic disorders may yield negative results $(6,7)$. The problem of rheumatoid factor interference can be reduced by removing rheumatoid factor by precipitation techniques, inactivation of rheumatoid factor by heating or diluting test sera. In the present case, rheumatoid factor was negative as measured by a latex agglutination slide test (Ortho Pharmaceuticals Ltd, Don Mills, Ontario) but only serum samples obtained after the initiation of immunosuppressive therapy were assayed and highly sensitive enzyme immunoassay or radioimmunoassay tests for rheumatoid factor were not done.

One can envision two mechanisms whereby rheumatoid factor might interfere with the anti-HAV $\lg M$ assay. The first is a virus antigen-independent false positive, where the $\lg M$ rheumatoid factor binds to the anti-IgM coupled to the bead matrix and when labelled antiHAV $\lg G$ is added, it is bound by the rheumatoid factor even though there is no HAV antigen bound to the matrix. The second type of false positive is anti- gen dependent and requires anti-HAV IgG in the test serum. The conjugation sequence here is matrix (anti-IgM) rheumatoid factor - anti-HAV $\operatorname{lgG}$ HAV antigen - anti-HAV IgG (peroxidase labelled). This type of interference is believed to require relatively high levels of rheumatoid factor (8).

An alternative explanation that would not invoke rheumatoid factor might simply be increased nonspecific adsorption of HAV antigen to the beads as a consequence of marked hyperglobulinemia in the test serum. This appears to be an attractive explanation for the results in the present case as the patient was markedly hyperglobulinemic at presentation and, when the immunoglobulin levels had normalized after several months of immunosuppressive treatment, the antiHAV IgM test result became negative. Furthermore, the low level of positivity is what would be expected in a situation where high 'background' rather than virus specific antibody was involved.

Similar false positive results have been described in other virus specific IgM antibody assays including those for rubella, toxoplasmosis and cytomegalovirus, and the frequency of such false positive results may reach $0.8 \%$ of patient samples tested $(6,8)$. It is perhaps surprising that there is apparently only one previous report of this problem in the antiHAV IgM assay (5). The present case illustrates the importance of considering the possibility of false positive results with this assay when clinical features of the illness are not in keeping with acute HAV infection. As well, reports of persistence of anti-HAV IgM for several years after acute infections (9) or descriptions of 'unusual' presentation of hepatitis A (10) need to be interpreted with consideration given to possible false positive anti-HAV $\mathrm{IgM}$ test results.

KJ. Petersdorf RG, Wilson JD, Martin JB, Fauci AS, eds. Harrison's Principles of Internal Medicine. New York: McGraw Hill, 1987:1325-38.

3. Decker RM, Kosakowski SM.

Vanderbilt AS, et al. Diagnosis of acute hepatitis $A$ by HAVAB-M, a direct radioimmunoassay for $\operatorname{lgM}$ anti-HAV Am J Clin Pathol 1981:76:140-7.

4. Storch GA, Bodicky C, Parker M, et al. Use of conventional and $\operatorname{lgM}$-specific radioimmunoassays for anti-hepatitis $\mathrm{A}$ antibody in an outbreak of hepatitis A. Am J Med 1982;73:063-8.

5. Bucens MR, Pietroboni GR, Harnett radioimmunoassay for hepatitis $A$ antibody for the lgM class. J Virol Methods 1983:7:287-95

6. Meurman O. Detection of antiviral $\operatorname{lgM}$ antibodies and its problems - A review In: Bachman PA, ed. Current Topics in GB. False positive results occurring in a 


\section{GRAY AND STEINBRECHER}

Microbiology and Immunology. New York: Springer Verlag, 1983;104:101-31.

7. Salonen E-M, Vaheri A, Suni ], Wager O. Rheumatoid factor in acute viral infections: Interference with determination of $\lg \mathrm{M}, \lg \mathrm{G}$, and $\lg \mathrm{A}$ antibodies in an enzyme immunoassay. J Infect Dis
$1980 ; 142: 250-5$.

8. Meurman $\mathrm{OH}, \mathrm{Ziola} \mathrm{BR.} \mathrm{IgM-class}$ rheumatoid factor interference in the solid-phase radioimmunoassay of rubella-specific $\lg M$ antibodies. J Clin Pathol 1978;31:483-7.

9. Kao HW, Ashcavai M, Redeker AG. The persistence of hepatitis A lgM antibody after acute clinical hepatitis $\mathrm{A}$. Hepatology 1984:4:933-6.

10. Gordon SC, Reddy KR. Schiff L, Schiff ER. Prolonged intrahepatic cholestasis secondary to acute hepatitis A. Ann Intern Med 1984:101:635-7. 


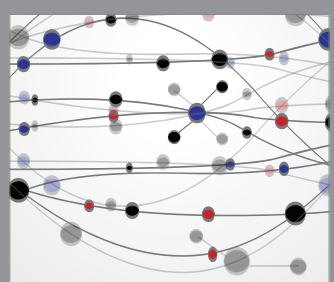

The Scientific World Journal
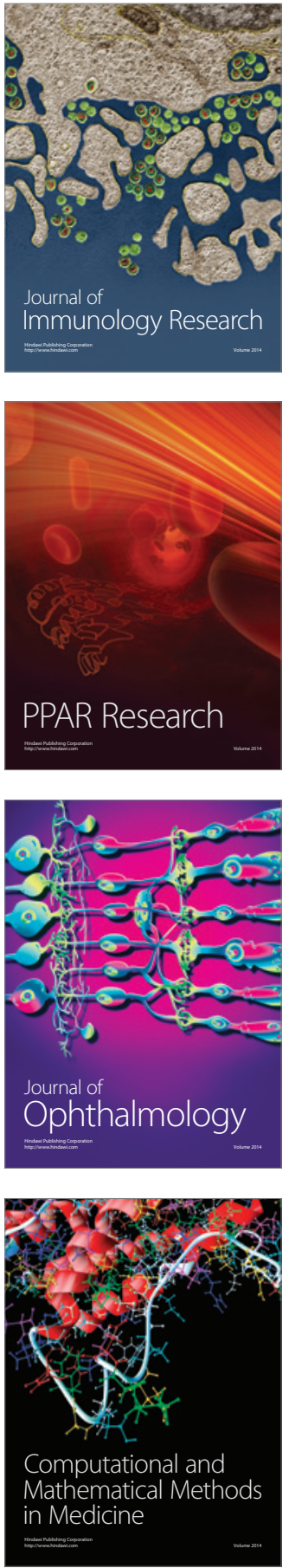

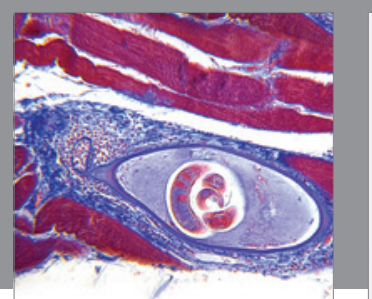

Gastroenterology Research and Practice

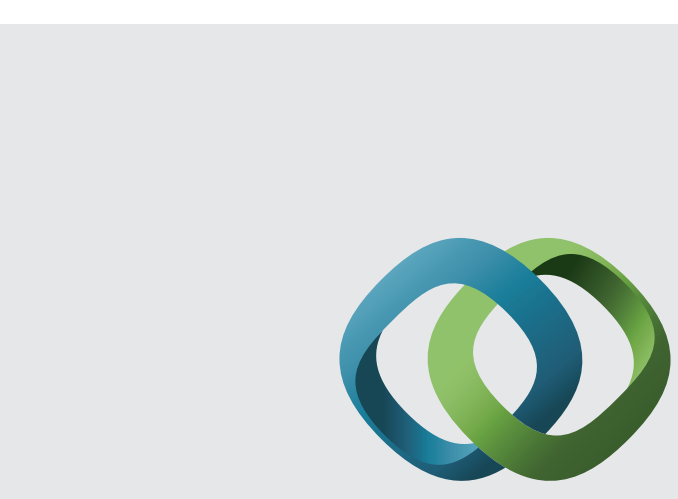

\section{Hindawi}

Submit your manuscripts at

http://www.hindawi.com
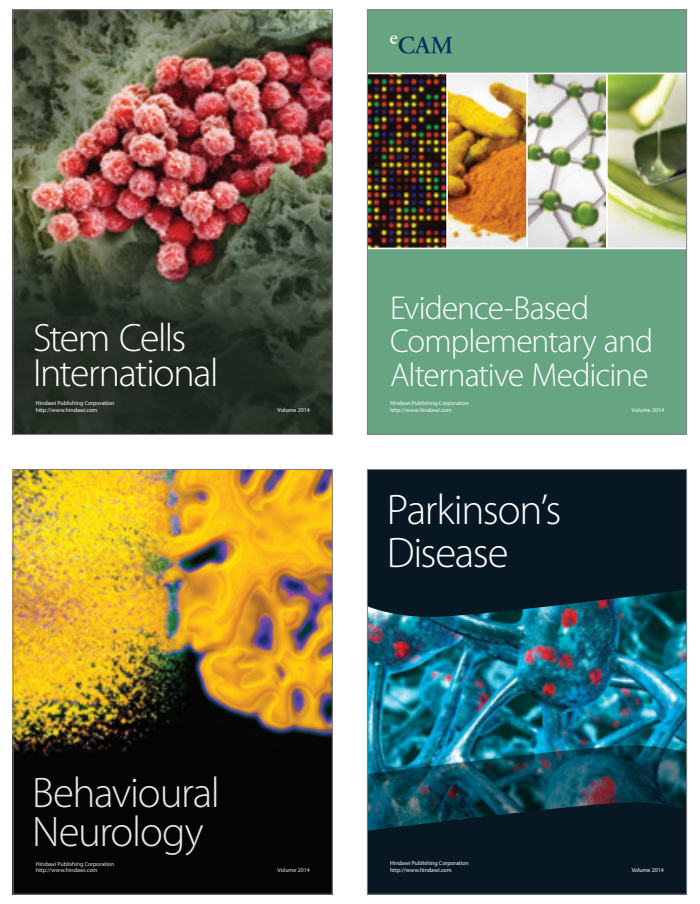
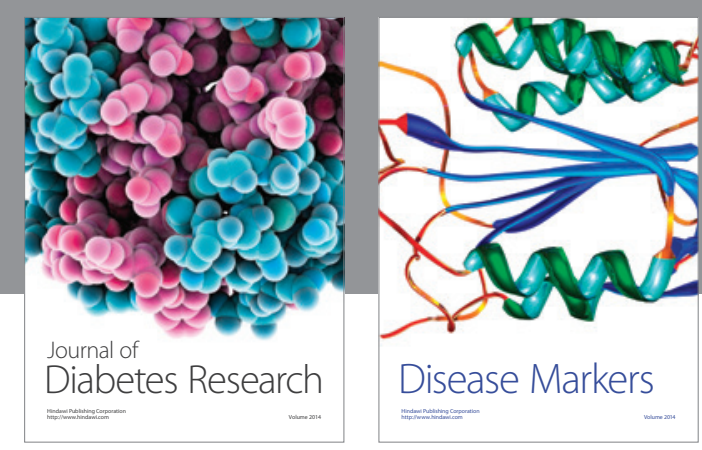

Disease Markers
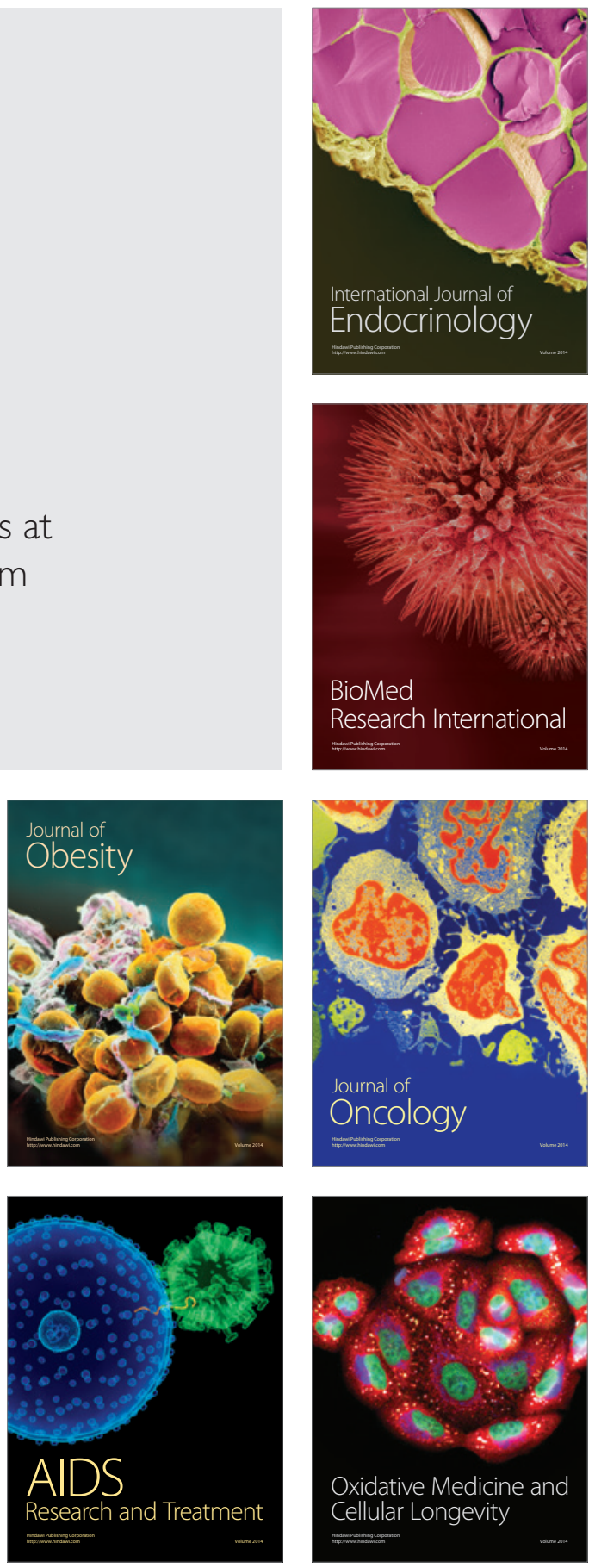